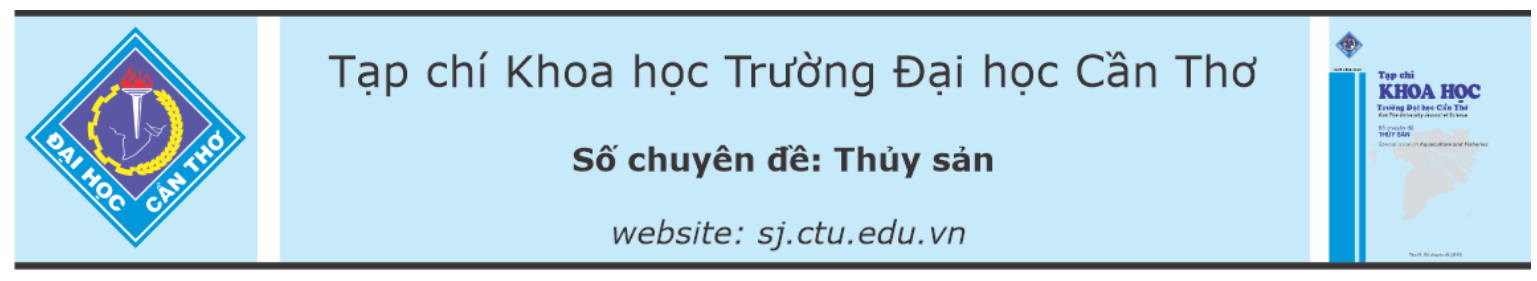

DOI:10.22144/ctu.jvn.2021.057

\title{
HIỆU QUẢ XỦ LÝ NƯỚC THẢI NUÔI CÁ TRÊ VÀNG (Clarias macrocephalus) THÂM CANH BÀ̀NG HỆ THỐNG THỤC VẬT THỦY SINH
}

\author{
Nguyễn Thị Hồng Nho ${ }^{1^{*}}$, Trương Quốc Phú ${ }^{2}$ và Phạm Thanh Liêm ${ }^{2}$ \\ ${ }^{1}$ Khoa Nông nghiệp và Tài nguyên môi truờng, Truoòng Đại học Đồng Tháp \\ ${ }^{2}$ Khoa Thủy sản, Truòng Đại học Cần Tho \\ *Ngưòi chịu trách nhiệm bài viết: Nguyễn Thị Hồng Nho (email: nthnho@dthu.edu.vn)
}

\section{Thông tin chung:}

Ngày nhận bài: 22/02/2021

Ngày nhận bài sủa: 22/04/2021

Ngày duyệt đăng: 01/06/2021

\section{Title:}

The efficiency of treating wastewater from intensive broadhead catfish (Clarias macrocephalus) culture by aquatic plant system

\section{Tù khóa:}

Bèo nhật, bèo tai tương, bèo tấm, cá trê vàng, hệ thống tuần hoàn

\section{Keywords:}

Clarias macrocephalus, Lemna minor, Limnobium laevigatum Pistia stratiotes, recirculating aquaculture system

\begin{abstract}
The study is aimed to identify macrophyte with capability of wastewater treatment in a recirculating aquaculture system. There were 4 treatments including Pistia stratiotes, Lemna minor, Limnobium laevigatum, and the control treatment (no plants). Broadhead catfish, Clarias macrocephalus (weight of $60 \mathrm{~g}$ each) were stocked at a density of 70 fish $100 \mathrm{~L}$ and fed to ad libitum with floating pellets ( $41 \%$ crude protein). The results revealed that Pistia stratiotes was the best macrophyte in treating wastewater discharged from the broadhead catfish culture system in the first 10 days of the experiment. The concentration of $\mathrm{CO}_{2}, \mathrm{COD}, \mathrm{TAN}, \mathrm{N}-\mathrm{NO}_{3}{ }^{-}, \mathrm{P}-$ $\mathrm{PO}_{4}{ }^{3-}$, and TP in wastewater reduced $65.83 \%, 34.28 \%, 40.70 \%, 46.70 \%$, $24.56 \%$, and $9.16 \%$, respectively while dissolved oxygen increased $37.68 \%$ compared to the initial concentration after treatment by Pistia stratiotes.
\end{abstract}

\section{TÓM TẮT}

Nghiên cứu được thực hiện nhằm tìm ra loài thực vật thủy sinh có khả năng xủ lý tốt chất thải trong hệ thống tuần hoàn nuôi trồng thủy sản. Thí nghiệm gồm 4 nghiệm thức trồng bèo tai tượng (Pistia stratiotes), bèo tấm (Lemna minor), bèo nhật (Limnobium laevigatum) và nghiệm thức đối chưng (không trồng thực vật) thực hiện trong hệ thống tuần hoàn trong 15 ngày. Cá trê vàng có khối luợng trung bình $60 \mathrm{~g} / \mathrm{con}$ được nuôi trong hệ thống tuần hoàn với mật độ 70 con/100L và cho ăn thức ăn viên nổi (41\% protein). Kết quả nghiên cứu cho thấy bèo tai tuợng xử lý tốt hầu hết các chất ô nhiếm trong nước thải nuôi cá trê vàng trong 10 ngày đầu thí nghiệm. Bèo tai tuợng có khả năng làm giảm 65,83\% $\mathrm{CO}_{2} ; 34,28 \%$

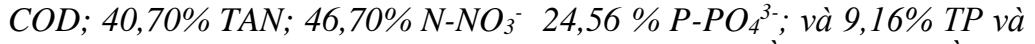
làm tăng 37,68\% oxy hòa tan trong nước thải so với nồng độ ban đầu.

\section{GIỚI THIỆU}

Hiện nay, các nước phát triển đã ứng dụng rất thành công hệ thống tuần hoàn trong sản xuất thâm canh trên các đối tượng cá nước ngọt và cá biển (Emmanuelle et al., 2009, Martins et al., 2010). Ở
Việt Nam, hệ thống tuần hoàn được áp dụng phổ biến trong các trại sản xuất giống tôm càng xanh (Nguyễn Thanh Phương và ctv., 2003) và đang được phát triển cho các mô hình ương nuôi cá tra, cá lóc, cá trê vàng (Nho et al., 2012; Cao Văn Thích và ctv., 2014; Nguyễn Thị Hồng Nho và ctv., 2018). Những 
lợi ích của hệ thống tuần hoàn gồm: giảm lượng nước tiêu thụ, cho phép nuôi cá quy mô lớn với một lượng nước nhỏ và chất thải ít hoặc không gây ô nhiễm, giúp cho việc quản lý chất thải và tái sử dụng chất dinh dưỡng, quản lý dịch bệnh tốt hơn (Tal et al., 2009) và kiểm soát ô nhiễm sinh học (không có sự thất thoát cá nuôi ra ngoài tự nhiên (Zohar et al., 2005). Hoạt động của hệ thống tuần hoàn nuôi thủy sản dựa trên quá trình loại bỏ chất thải rắn ở hệ thống lắng, lọc và loại bỏ chất thải hòa tan ở bể lọc sinh học nhờ quá trình nitrate hóa. Quá trình nitrate hoá là quá trình oxy hoá amoniac $\left(\mathrm{NH}_{3}\right)$ thành nitrite $\left(\mathrm{NO}_{2}\right)$ sau đó lại được oxy hoá thành nitrate $\left(\mathrm{NO}_{3}\right)$ nhờ vi khuẩn nitrate hoá tự dưỡng như Nitrosomonas và Nitrobacter. Tuy nhiên, nồng độ nitrate trong hệ thống tuần hoàn đến cuối quá trình nuôi rất cao, lên đến trên $30 \mathrm{mg} / \mathrm{L}$ ở hệ thống nuôi cá trê vàng có thay nước vào cuối vụ nuôi (Nguyễn Thị Hồng Nho và ctv., 2019). Đồng thời nồng độ $\mathrm{PO}_{4}{ }^{3-}$ trong hệ thống tuần hoàn cũng khá cao, trên $8 \mathrm{mg} / \mathrm{L}$ trong ương cá tra không thay nước (Nguyễn Thị Hồng Nho, 2013) và trên $5 \mathrm{mg} / \mathrm{L}$ trong nuôi cá trê vàng có thay nước vào cuối vụ nuôi (Nguyễn Thị Hồng Nho và ctv., 2019). Hàm lượng $\mathrm{NO}_{3}{ }^{-}$và $\mathrm{PO}_{4}{ }^{3-}$ cao trong môi trường nước sẽ kích thích sự phát triển quá mức của tảo (hiện tượng nở hoa của tảo) trong ao và tiến trình phân hủy tảo sẽ làm cho môi trường nước bị ô nhiễm, thiếu oxy cung cấp cho hoạt động hô hấp trong thủy vực; nếu nước thải chứa hàm lượng $\mathrm{NO}_{3}{ }^{-}$và $\mathrm{PO}_{4}{ }^{3-}$ cao được thải trực tiếp ra kênh rạch có thể sẽ gây ô nhiễm môi trường và nguồn nước sử dụng cho sinh hoạt.

Thực vật thủy sinh đang là một trong những giải pháp hữu hiệu cho xử lý nước thải, vai trò của chúng trong xử lý nước thải đã được nghiên cứu trong và ngoài nước. Trương Thị Nga và ctv. (2007) đã nghiên cứu sử dụng bèo tai tượng $(P$. stratiotes) và bèo tai chuột (S. cucullata) để xử lý nước thải từ hoạt động chăn nuôi gia súc và kết quả đạt được rất khả quan. Bèo còn có tác dụng cung cấp oxy làm cải thiện oxy hoà tan trong môi trường nước thải, góp phần làm trong sạch nguồn nước. Một số loại bèo còn được dùng làm phân xanh, thức ăn cho cá, gia súc, gia cầm. Nghiên cứu của Wafaa et al. (2007) cho thấy bèo tấm $(L . g i b b a)$ xử lý các chất ô nhiễm trong nước thải một cách hiệu quả, ngoài ra bèo tấm còn có khả năng loại bỏ các hợp chất hữu cơ, một số kim loại nặng, phiêu sinh vật và một số vi khuẩn bất lợi trong nước thải. Mặc dù có nhiều nghiên cứu về các loài thực vật xử lý nước thải trong nuôi trồng thủy sản và chăn nuôi, nhưng những thông tin về hệ thống thực vật xử lý nước thải trong hệ thống tuần hoàn nuôi trồng thủy sản ở Việt Nam vẫn còn rất hạn chế. Nghiên cứu này đánh giá và lựa chọn loài thực vật phổ biến ở Việt $\mathrm{Nam}$ có khả năng xử lý tốt $\mathrm{NO}_{3}{ }^{-}$ và $\mathrm{PO}_{4}{ }^{3-}$ trong hệ thống tuần hoàn, từ đó làm cơ sở cho việc thiết kế và vận hành hệ thống tuần hoàn kết hợp nuôi và xử lý chất thải cho cá trê vàng.

\section{PHƯONG PHÁP NGHIÊN CỨU}

\subsection{Bố trí thí nghiệm}

Thí nghiệm được thực hiện trong nhà và được bố trí hoàn toàn ngẫu nhiền trong hệ thống tuần hoàn nước với mật độ cá trê vàng là $70 \mathrm{con} / 100 \mathrm{~L}$ với 4 nghiệm thức (NT) trồng thực vật khác nhau bao gồm (i) NT1- bèo tai tượng (Pistia stratiotes), (ii) NT2 bèo tấm (Lemna minor), (iii) NT3 - bèo nhật (Limnobium laevigatum) và (iv) NT4 - đối chứng (không trồng thực vật), mỗi nghiệm thức được lặp lại 3 lần và thời gian thí nghiệm là 15 ngày. Cấu phần của hệ thống tuần hoàn bao gồm bể nuôi có thể tích $100 \mathrm{~L}$, bể lắng $30 \mathrm{~L}$, bể chứa $70 \mathrm{~L}$ và bể lọc sinh học giá thể chuyển động $70 \mathrm{~L}$. Bể lọc sinh học sử dụng giá thể nhựa RK-Plast (có diện tích riêng bề mặt $750 \mathrm{~m}^{2} / \mathrm{m}^{3}$ ) với tổng diện tích bề mặt giá thể là $30 \mathrm{~m}^{2}$ (40 L giá thể). Hệ thống trồng thực vật gồm 3 máng nhựa $(35 \times 40 \times 20 \mathrm{~cm})$ được nối với nhau và nối với hệ thống tuần hoàn nuôi cá trê. Nước đầu vào của hệ thống trồng thực vật được dẫn từ bể lọc sinh học và nước đầu ra được đưa đến bể nuôi (Hình 1). Thực vật được trồng hết diện tích của cả 3 máng trồng thực vật cho mỗi nghiệm thức. Thí nghiệm được bố trí hệ thống đèn led chiếu sáng vào ban ngày để bổ sung ánh sáng cho thực vật phát triển (hệ thống thí nghiệm đạt $2.000-4.000$ lux vào buổi sáng, 9.000 - 11.000 lux vào buổi trưa và 20.000 25.000 lux vào buổi chiều; độ dao động phụ thuộc vào điều kiện thời tiết).

Cá thí nghiệm có trọng lượng trung bình khoảng $60 \mathrm{~g} / \mathrm{con}$. Cá được cho ăn 2 lần/ngày bằng thức ăn công nghiệp $41 \%$ protein. $\mathrm{NaHCO}_{3}$ được bổ sung khi $\mathrm{pH}$ giảm ở nghiệm thức đối chứng để duy trì $\mathrm{pH}$ trong khoảng 7,0-8,5. 


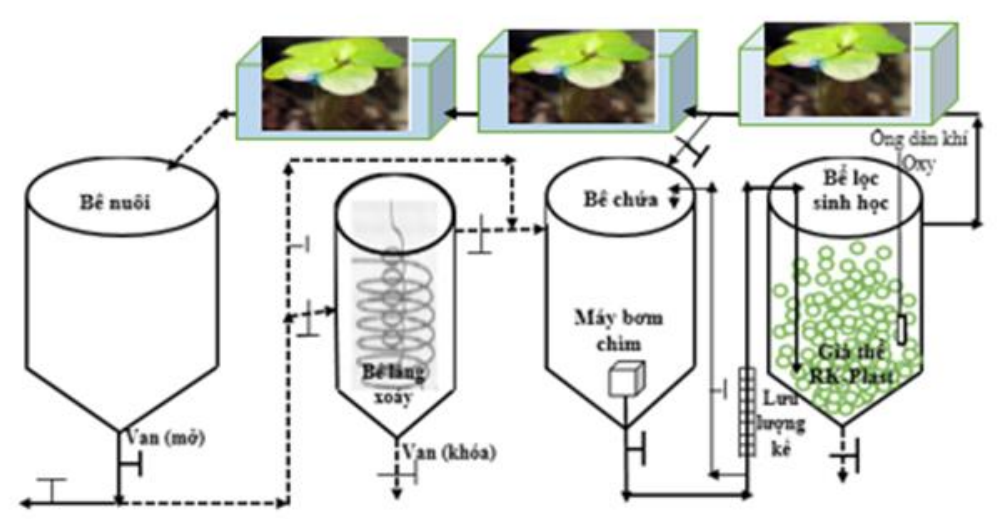

\section{Hình 1. Hệ thống thực vật xử lý nước thải trong hệ thống tuần hoàn}

Các loài thực vật nghiên cứu được chọn là loại tự nhiên và thu thập từ các vùng ven nội ô thành phố Cao Lãnh. Bèo tai tượng, bèo nhật được chọn làm giống là những cây phát triển khỏe mạnh, không bị sâu bệnh và tương đối đồng đều nhau về chiều cao và trong cùng giai đoạn sinh trưởng. Cây con được cắt bỏ và để trong môi trường nước 2 ngày cho bèo quen dần với điều kiện trên bể nhỏ.

\subsection{Các chỉ tiêu theo dõi trong quá trình nuôi}

Các yếu tố nhiệt độ, $\mathrm{pH}, \mathrm{DO}, \mathrm{CO}_{2}$, độ kiềm, TSS, $\mathrm{COD}, \mathrm{TAN}, \mathrm{N}-\mathrm{NO}_{2}^{-}, \mathrm{N}-\mathrm{NO}_{3}^{-}, \mathrm{P}-\mathrm{PO}_{4}{ }^{3-}, \mathrm{TN}$ và $\mathrm{TP}$ được thu 5 ngày/lần ở đầu ra của hệ thống trồng thực vật. Nhiệt độ được đo bằng nhiệt kế thủy ngân. $\mathrm{pH}$ được đo bằng thiết bị đo $\mathrm{pH}$ HANA. Các chỉ tiêu môi trường nước còn lại được thu và phân tích theo American Public Health Association et al. (1995).

Trong quá trình thí nghiệm, việc theo dõi và loại bỏ thực vật bị chết ra khỏi hệ thống máng trồng thực vật được thực hiện thường xuyên.

\subsection{Phương pháp xử lý số liệu}

Số liệu trung bình, độ lệch chuẩn về tăng trưởng, tỉ lệ sống, được tính toán trên phần mềm Excel 2016. Khác biệt giá trị trung bình giữa các nghiệm thức được phân tích bằng ANOVA một nhân tố, theo sau là phép kiểm định Duncan sử dụng phần mềm SPSS 20.0 ở mức ý nghĩa 0,05 .

\section{KẾT QUẢ VÀ THẢO LUẬN}

Trong quá trình thí nghiệm, nhiệt độ trung bình giữa các nghiệm thức dao động trong khoảng $27,63 \pm 0,95^{\circ} \mathrm{C}$. Hệ thống nuôi được sục khí liên tục nên hàm lượng oxy hòa tan luôn được duy trì $>2$ $\mathrm{mg} / \mathrm{L}$; hàm lượng oxy này sẽ giúp hoạt động của vi khuẩn phát triển bình thường. Bên cạnh đó, hàm lượng $\mathrm{CO}_{2}$ cũng giảm bớt một phần nhờ quá trình sục khí ở bể lọc sinh học. $\mathrm{pH}$ và độ kiềm tăng đến ngày thứ 10 ở các NT trồng thực vật. Hàm lượng N$\mathrm{NO}_{3}{ }^{-}, \mathrm{COD}, \mathrm{PO}_{4}{ }^{3-}$ giảm ở ngày thứ 10 và tăng lại vào ngày thứ 15 .

\subsection{Biến động pH độ kiềm}

Trong quá trình thí nghiệm, pH ở NT bèo tai tượng là cao nhất và thấp nhất ở NT đối chứng, dao động từ $7,0-8,5, \mathrm{pH}$ giữa các NT ở các ngày thu mẫu khác biệt không có ý nghĩa thống kê $(\mathrm{p}>0,05)$. Trong quá trình thí nghiệm, $\mathrm{pH}$ và độ kiềm ở NT bèo tai tượng và bèo nhật tăng từ ngày 1 đến ngày 10 của thí nghiệm (Hình 2 ). Điều này có thể là do ở các NT trồng thực vật, quá trình quang hợp của thực vật làm tăng $\mathrm{pH}$, tăng độ kiềm và giảm nồng độ $\mathrm{CO}_{2}$ trong nước (Boyd, 1990). Ngược lại, ở NT đối chứng, $\mathrm{pH}$ và độ kiềm giảm ở ngày thứ 5 của thí nghiệm, sau đó tăng trở lại. Nguyên nhân là do trong hệ thống tuần hoàn, vi khuẩn nitrate hóa sử dụng các ion kiềm để chuyển hóa $\mathrm{NH}_{4}{ }^{+}$thành $\mathrm{NO}_{3}^{-}$làm độ kiềm và $\mathrm{pH}$ giảm (Timmons \& Ebeling, 2010); khi $\mathrm{pH}$ giảm, $\mathrm{NaHCO}_{3}$ được bổ sung để duy trì $\mathrm{pH}$ ở mức thích hợp cho vi khuẩn nitrate hóa hoạt động. Hình 2 cũng cho thấy $\mathrm{pH}$ và độ kiềm ở ngày thứ 15 của $\mathrm{NT}$ bèo tai tượng và bèo tấm giảm, trong khi $\mathrm{pH}$ và độ kiềm ở NT bèo nhật lại tăng. Nguyên nhân là do sau ngày thí nghiệm thứ 10 , bèo tai tượng và bèo tấm bắt đầu có dấu hiệu tàn, nhưng bèo nhật vẫn còn phát triển tốt đến ngày thứ 15 . Masser et al. (1999) cho rằng độ kiềm trong hệ thống tuần hoàn tốt nhất dao động từ 50 đến lớn hơn hoặc bằng $100 \mathrm{mg}$ $\mathrm{CaCO}_{3} / \mathrm{L}$, trong khi đối với kết quả nghiên cứu của Boyd (1990), độ kiềm < 10mg $\mathrm{CaCO}_{3} / \mathrm{L}$ sẽ ảnh hưởng đến sinh trưởng và phát triển của cá; hàm

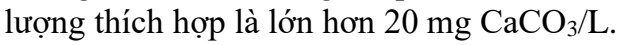



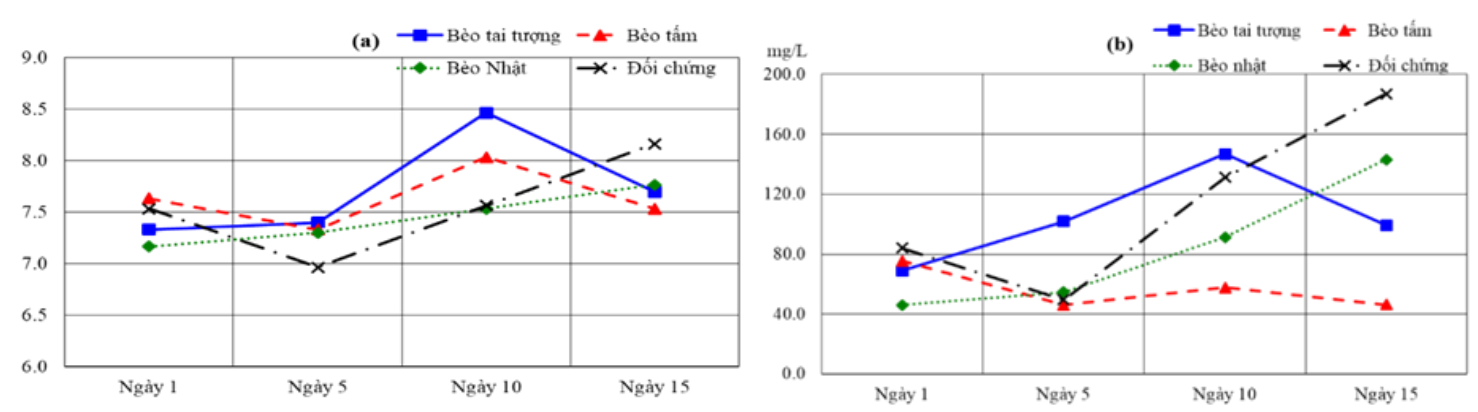

Hình 2. Biến động pH (a) và độ kiềm (b) trong hệ thống thí nghiệm

Kết quả thí nghiệm cũng cho thấy khi kết hợp thực vật xử lý nước, độ kiềm và $\mathrm{pH}$ trong nước tăng trong 10 ngày đầu mà không cần phải bổ sung $\mathrm{NaHCO}_{3}$ như ở NT đối chứng. Độ kiềm của nghiệm thức bèo tai tượng và NT đối chứng ở ngày thứ 10 khác biệt không có ý nghĩa thống kê $(\mathrm{P}>0,05)$. Theo qui chuẩn nước mặt QCVN 08-MT:2015/BTNMT, $\mathrm{pH}$ có giá trị từ $6,0-8,5$ là thích hợp cho nước dùng trong sinh hoạt, trong khi đó theo qui chuẩn nước thải QCVN 24:2009/BTNMT, nước thải có $\mathrm{pH}$ từ 5,5-9 được phép thải ra môi trường. So với những tiêu chuẩn này, chất lượng nước sau xử lý đạt yêu cầu và không tổn hại đến môi trường thủy sinh.

\subsection{Biến động oxy hòa tan và $\mathrm{CO}_{2}$}

Hàm lượng oxy hòa tan trong nước ở các NT bèo tấm, bèo tai tượng và bèo nhật có xu hướng tăng theo thời gian thí nghiệm, ngược lại, oxy hòa tan ở NT đối chứng lại giảm theo thời gian thí nghiệm (Hình 3). Ở ngày thứ 10 của thí nghiệm, oxy hòa tan ở NT bèo tai tượng tăng mạnh hơn các nghiệm thức còn lại, lên đến $5,60 \pm 0,49 \mathrm{mg} / \mathrm{L}$ (tăng 37,68\% so với lúc bố trí thí nghiệm) và khác biệt có ý nghĩa thống kê $(\mathrm{p}<0,05)$ với $2 \mathrm{NT}$ bèo nhật và $\mathrm{NT}$ đối chứng. Nguyên nhân là do quá trình quang hợp của thực vật trong các nghiệm thức bèo tấm, bèo tai tượng và bèo nhật cung cấp oxy hòa tan cho hệ thống thí nghiệm. Một số nghiên cứu cho thấy thực vật thủy sinh được

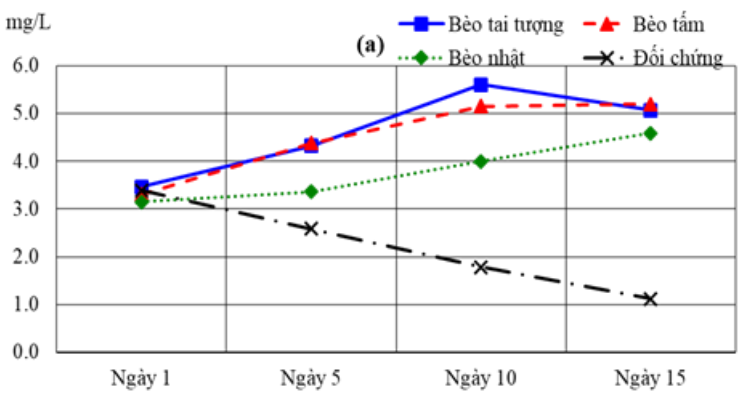

sử dụng như một hệ thống lọc sinh học trong nuôi trồng thủy sản và làm tăng đáng kể lượng oxy trong các hệ thống nuôi trồng thủy sản (Ferdoushi et al., 2008; Velichko \& Sirakov, 2013). Theo Trịnh Xuân Ngọ và Đinh Thế Lộc (2011), có khoảng 90 - 95\% sản phẩm thu hoạch của cây trồng lấy từ khí $\mathrm{CO}_{2}$ và $\mathrm{H}_{2} \mathrm{O}$ thông qua hoạt động quang hợp của lá cây, diện tích lá chính là cơ quan quang hợp để tạo nên chất hữu cơ tích lũy vào cây trồng tạo năng suất. Về mặt cấu tạo, bèo tai tượng có nhiều lá hơn và diện tích lá to hơn nhiều so với bèo nhật và bèo tấm, do đó lượng oxy được cung cấp cho hệ thống thí nghiệm sử dụng bèo tai tượng cũng cao hơn hai nghiệm thức bèo nhật và bèo tấm (trong cùng diện tích bề mặt nước xử lý). Ngược lại, oxy hòa tan trong NT đối chứng chịu ảnh hưởng chủ yếu bởi mức tiêu hao oxy từ quá trình hô hấp của cá nuôi, vi khuẩn nitrate hóa và quá trình phân hủy vật chất hữu cơ trong hệ thống, trong khi khả năng cung cấp oxy chỉ nhờ vào hệ thống sục khí. Oxy hòa tan của NT đối chứng ở ngày thứ 10 và 15 khác biệt có ý nghĩa thống kê so với các nghiệm thức còn lại $(\mathrm{p}<0,05)$. Theo Timmons \& Ebeling (2010), nồng độ oxy hòa tan nên được giữ ở $60 \%$ độ bão hòa (khoảng $5 \mathrm{mg} / \mathrm{L}$ ) để đảm bảo sự tồn tại và tăng trưởng của các loài nuôi, đồng thời có thể đảm bảo an toàn cho lọc sinh học hoạt động thì oxy hòa tan ở thí nghiệm này vẫn nằm trong giới hạn thích hợp cho cá nuôi.

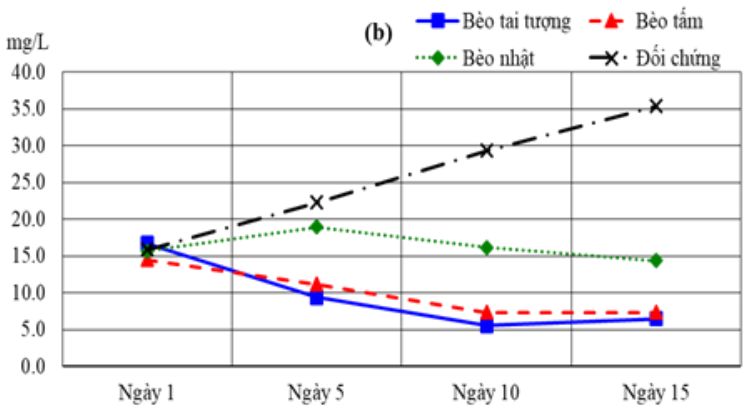

Hình 3. Biến động oxy hòa tan (a) và $\mathrm{CO}_{2}$ (b) trong hệ thống thí nghiệm

Hình 3 cũng cho thấy hàm lượng $\mathrm{CO}_{2}$ ở NT bèo tai tượng thấp nhất, và $\mathrm{CO}_{2}$ ở $\mathrm{NT}$ đối chứng là cao nhất và khác biệt có ý nghĩa thống kê $(\mathrm{p}<0,05)$ ở các ngày 5,10 và 15 . Hàm lượng $\mathrm{CO}_{2}$ của các $\mathrm{NT}$ 
xử lý nước bằng thực vật ở ngày thứ 10 giảm mạnh, đặc biệt là ở NT bèo tai tượng, dao động $5,57 \pm 1,11$ mg/L (giảm 65,83\% so với lúc mới bố trí thí nghiệm). Nguyên nhân là do thực vật thủy sinh đã sử dụng $\mathrm{CO}_{2}$ trong quá trình quang hợp. Trong khi đó, $\mathrm{CO}_{2}$ ở ngày thứ 10 của $\mathrm{NT}$ đối chứng tăng mạnh, từ $29,33 \pm 0,92 \mathrm{mg} / \mathrm{L} \cdot \mathrm{CO}_{2}$ ở $\mathrm{NT}$ đối chứng cao là do hô hấp của thủy sinh vật (chủ yếu là cá) trong bể nuôi và quá trình phân hủy vật chất hữu cơ.

\subsection{Biến động COD và TSS}

Hàm lượng COD ở các NT biến động qua các lần thu mẫu phụ thuộc vào sự phát triển của thực vật thủy sinh và sự lắng tụ của các chất hữu cơ trong nước. Hàm lượng COD ở NT đối chứng có xu hướng tăng dần về cuối thí nghiệm và cao hơn các NT còn lại (Hình 4). Hiệu suất xử lý COD ở các NT trồng thực vật sau 10 ngày cao nhất ở NT bèo tai tượng $(34,28 \%)$ và thấp nhất là ở NT bèo tấm $(10,23 \%)$. Nguyên nhân là do ở các NT có kết hợp trồng thực vật xử lý nước, các cây thủy sinh lấy carbon dioxide và oxy mà chúng cần từ không khí; dưới điều kiện

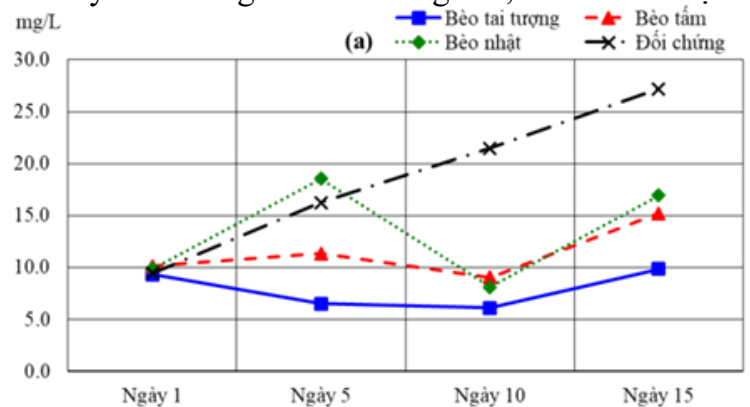

Hình 4. Biến động COD (a) và TSS (b)

Hình 4 cũng cho thấy hàm lượng TSS tăng dần theo thời gian thí nghiệm và có giá trị cao nhất ở NT đối chứng $(0,124 \pm 0,073 \mathrm{mg} / \mathrm{L})$ nhưng giảm dần từ ngày 1 đến ngày 10 ở NT bèo tai tượng. Nguyên nhân là do thực vật có khả năng lọc các chất thải qua vùng rễ (Rhizofiltration), các chất ô nhiễm sẽ được hấp phụ trên bề mặt rễ hoặc kết tủa với tác dụng của các dịch tiết ra từ rễ cây (the Interstate Technology and Regulatory Council, 2009). Đồng thời chất thải rắn cũng được loại bỏ với các loài thực vật nổi có hệ thống rễ rộng lớn (Dinges 1982; Metcalf \& Eddy, 1991). Do vậy hàm lượng TSS giảm ở các NT có trồng thực vật và giảm nhiều nhất ở NT bèo tai tượng. European Inland Fisheries Advisory Commission (1980) đề nghị tổng vật chất lơ lửng nên duy trì thấp hơn $15 \mathrm{mg} / \mathrm{l}$ để hệ thống tuần hoàn hoạt động được đảm bảo, trong khi Muir (1982) cho rằng khoảng giới hạn thích hợp là từ 20 đến $40 \mathrm{mg} / \mathrm{l}$, như vậy kết quả của nghiên cứu này nằm trong mức cho phép. yếm khí, nhiều loài trong số các loài thực vật này vận chuyển oxy đến rễ của chúng cho mục đích trao đổi chất. Oxy dư thừa sau đó có sẵn cho các loài sống xung quanh (Reddy et al., 1989). Khi rễ của cây nằm trong cột nước, chúng hoạt động như một chất nền sống cho sự tăng trưởng kèm theo của vi khuẩn hiếu khí, chúng sử dụng oxy dư thừa để phân giải các hợp chất hữu cơ hòa tan trong nước, do đó lượng COD thấp hơn ở các NT có trồng thực vật. Theo Tanner et al. (2002), các loài thực vật thủy sinh bậc cao có thể có tác động đến tình trạng oxy hóa của các trầm tích trong đất ngập nước kiến tạo bằng cách giải phóng oxy từ rễ và thân rễ của chúng vào trong vùng rễ và do đó giúp tăng sự phân hủy hiếu khí. Hàm lượng COD cao nhất là ở các NT trồng thực vật là $18,53 \pm 1,85 \mathrm{mg} / \mathrm{L}$, vẫn còn thấp so với tiêu chuẩn chất lượng nước thải công nghiệp của Bộ Tài nguyên và Môi trường (QCVN 40:2011/ BTNMT- hàm lượng COD trong nước thải công nghiệp xả vào nguồn nước được dùng cho nước cấp sinh hoạt cho phép tối đa là $75 \mathrm{mg} / \mathrm{L}$ ).

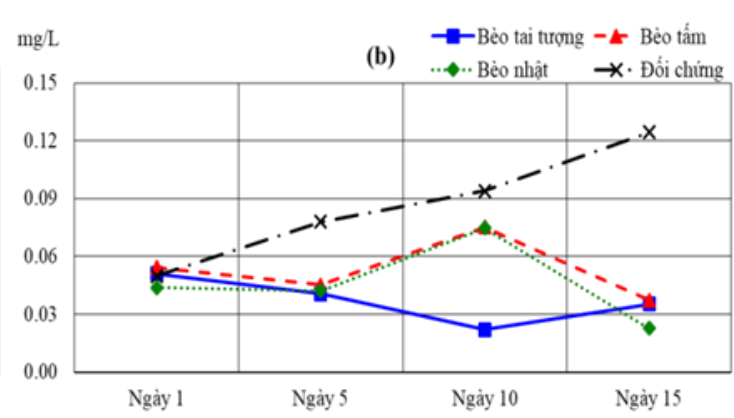

(b) trong hệ thống thí nghiệm

\subsection{Biến động $\mathrm{TAN}$ và $\mathrm{NO}_{2}$}

Hàm lượng TAN của các NT có kết hợp trồng thực vật thấp hơn nghiệm thức đối chứng sau 10 ngày thí nghiệm, TAN thấp nhất là ở NT bèo tai tượng và cao nhất ở $\mathrm{NT}$ đối chứng (Hình 5 ) và khác biệt có ý nghĩa thống kê ( $\mathrm{p}>0,05)$. Nguyên nhân là do thực vật thủy sinh có thể hấp thu đạm ở dạng vô cơ như $\mathrm{N}^{-N_{4}}{ }^{+}$(Cao et al., 2004; Nimptsch \& Pflugmacher, 2007). Theo Lê Hoàng Việt và Nguyễn Võ Châu Ngân (2014), thực vật thủy sinh có khả năng loại bỏ các loại chất thải hòa tan trong thủy vực. Đạm trong nước thải có thể bị loại bỏ bởi các cơ chế sau (i) bị hấp thu bởi thực vật và sau đó thực vật được thu hoạch và đưa ra khỏi hệ thống, (ii) sự bay hơi của ammoniac và (iii) quá trình nitrate hóa và khử nitrate của các vi sinh vật.

Ở các NT có trồng thực vật, hiệu suất xử lý TAN sau 10 ngày thí nghiệm cao nhất ở NT bèo tai tượng $(40,70 \%)$, tiếp đến là NT bèo nhật $(17,06 \%)$. Ở NT 
bèo tấm chưa thấy được hiệu suất xử lý TAN sau cả 10 và 15 ngày thí nghiệm. Theo Lai et al. (2011), hệ thống rễ cây là nơi hấp thu chất dinh dưỡng, khả năng hấp thu chất dinh dưỡng tương quan với diện tích bề mặt rễ và rễ cây cũng là môi trường sống

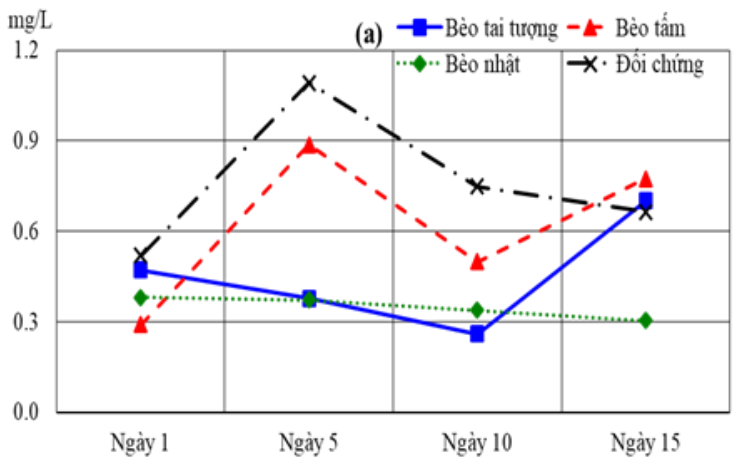

Hình 5. Biến động TAN (a) và NO2 thích hợp cho sinh trưởng và phát triển của các loài vi sinh vật. Do bèo tai tượng có hệ rễ phát triển và diện tích bề mặt cao hơn nhiều so với bèo nhật và bèo tấm nên hiệu suất xử lý TAN của bèo tai tượng cũng cao hơn.

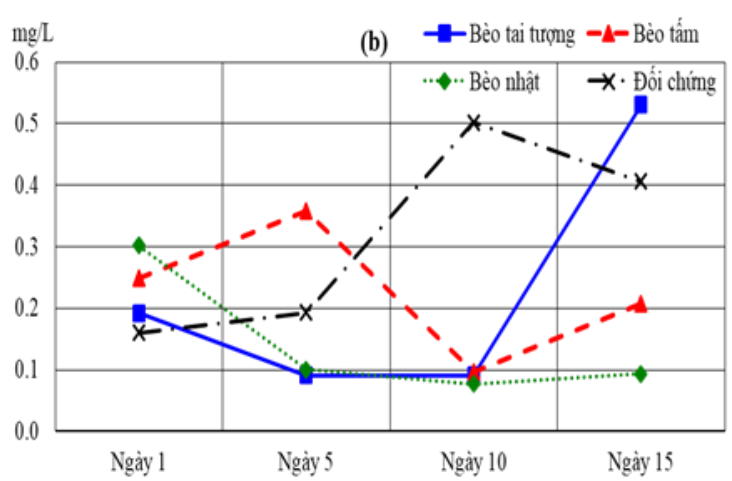

(b) trong hệ thống thí nghiệm

Hàm lượng $\mathrm{N}-\mathrm{NO}_{2}{ }^{-}$ơ các $\mathrm{NT}$ có trồng thực vật giảm thấp nhất ở ngày thu mẫu thứ 10 tăng trở lại vào ngày thứ 15 . Nguyên nhân là do từ ngày 1 đến ngày 10 , các loài thực vật thí nghiệm phát triển tốt, làm tăng độ kiềm, $\mathrm{pH}$ và $\mathrm{Oxy}$ trong hệ thống thí nghiệm, do đó hoạt động của các nhóm vi khuẩn nitrate hóa trong hệ thống tốt hơn. Sau ngày 10 đến ngày 15 của thí nghiệm, các nhóm bèo bắt đầu chết dần trong hệ thống thí nghiệm, đặc biệt là bèo tai tượng. Do đó hàm lượng $\mathrm{NO}_{2}{ }^{-}$tăng mạnh ở $\mathrm{NT}$ này, lên đến $0,53 \pm 0,14 \mathrm{mg} / \mathrm{L}$. Theo Masser et al. (1999), hàm lượng $\mathrm{N}-\mathrm{NO}_{2}{ }^{-}$trong hệ thống tuần hoàn nên < $0,5 \mathrm{mg} / \mathrm{L}$ và theo $\mathrm{Boyd}(1998), \mathrm{N}-\mathrm{NO}_{2}{ }^{-}$có tác dụng gây độc cho tôm cá khi lớn hơn $2 \mathrm{mg} / \mathrm{L}$. Như vậy, mức dao động của thí nghiệm này (dưới $2 \mathrm{mg} / \mathrm{L}$ ) là phù hợp và ít ảnh hưởng đến sự sinh trưởng và phát triển của cá.

\subsection{Biến động $\mathrm{N}-\mathrm{NO}_{3}{ }^{-}$và $\mathrm{TN}$}

Hàm lượng $\mathrm{N}-\mathrm{NO}_{3}{ }^{-}$có xu hướng giảm từ ngày 1 đến ngày 10 của các NT trồng thực vật và tăng ở NT đối chứng (Hình 6). Nguyên nhân cũng là do ở các NT trồng thực vật thủy sinh thì các loài thực vật này cũng có thể hấp thu một số đạm ở dạng vô cơ như $\mathrm{N}-\mathrm{NH}_{4}{ }^{+}$và $\mathrm{N}-\mathrm{NO}_{3}{ }^{-}$. Ngược lại, ở $\mathrm{NT}$ đối chứng, quá trình chuyển hóa của các nhóm vi khuẩn nitrate hóa trong hệ thống lọc sinh học làm cho nồng độ $\mathrm{N}-\mathrm{NO}_{3}{ }^{-}$ ngày càng tăng theo thời gian thí nghiệm. Nồng độ $\mathrm{NO}_{3}{ }^{-}$ở các $\mathrm{NT}$ bèo tai tượng, bèo tấm và bèo nhật ở ngày thứ 10 khác biệt không có ý nghĩa thống kê $(\mathrm{p}>0,05)$ và khác biệt có ý nghĩa thống kê với $\mathrm{NT}$ đối chứng $(\mathrm{p}<0,05)$. Hiệu suất loại bỏ $\mathrm{N}-\mathrm{NO}_{3}{ }^{-}$ở các NT trồng thực vật lần lượt là $46,70 \%$ ở NT bèo tai tượng, $45,02 \%$ ở NT bèo tấm và $32,19 \%$ ở NT bèo nhật sau 10 ngày thí nghiệm. Việc loại bỏ nitrate trong RAS chủ yếu được thực hiện bởi các thực vật thủy sinh. Kết quả nghiên cứu của Alabaster \& Lloyd (1980) cho thấy rằng các thực vật thủy sinh có hiệu quả cao trong việc loại bỏ nitrate khỏi nước nuôi trồng thủy sản. Theo Li et al. (2015), nitrate trong thủy vực được loại bỏ thông qua quá trình đồng hóa của thực vật thủy sinh.

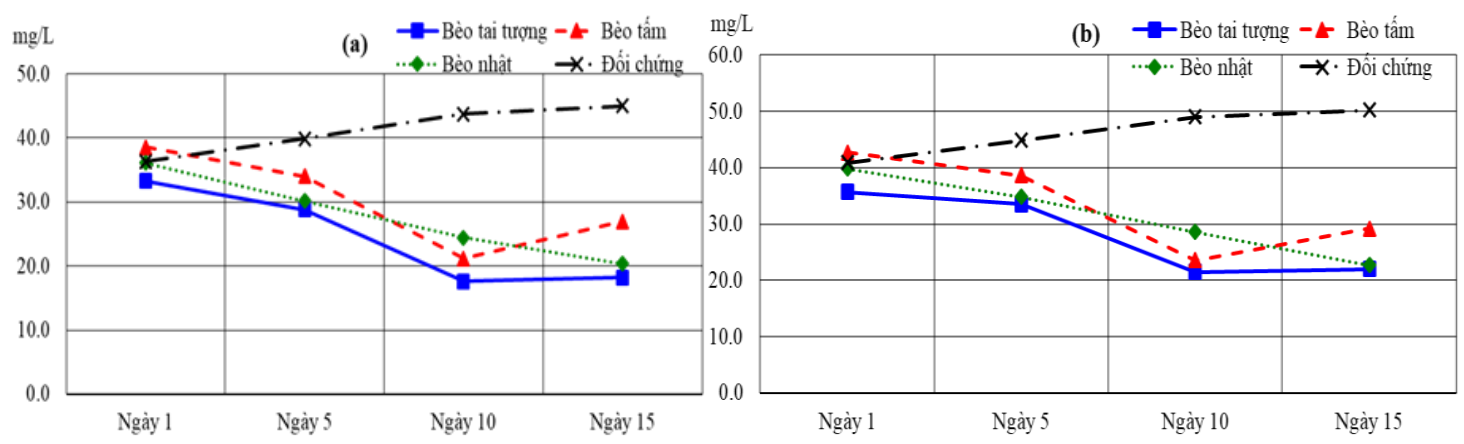

Hình 6. Biến động N-NO ${ }^{-}$(a) và TN (b) trong hệ thống thí nghiệm 
Hình 6 cũng cho thấy hàm lượng $\mathrm{TN}$ của các NT bèo tai tượng, bèo tấm và bèo nhật thấp hơn NT đối chứng. TN của NT bèo tai tượng, bèo tấm và bèo nhật có xu hướng giảm dần từ ngày 1 đến ngày 10 của thí nghiệm, và thấp nhất ở NT bèo tai tượng $(21,99 \pm 5,56 \mathrm{mg} / \mathrm{L})$. Điều này là do các loài thực vật có khả năng hấp thu đạm ở dạng vô cơ và không hấp thu đạm ở dạng hữu cơ nên tổng đạm $\mathrm{TN}$ ở các nghiệm thức giảm sau 10 ngày thí nghiệm, nguyên nhân chủ yếu do TAN và $\mathrm{NO}_{3}^{-}$được thực vật thủy sinh hấp thu. Một nghiên cứu của Henry - Silva \& Camargo (2006) ở Brazil về khả năng xử lý nước thải ao nuôi cá rô phi trong 14 tuần cho thấy trong diện tích bể thí nghiệm $4 \mathrm{~m}^{2}$ bèo tai tượng (Pistia stratiotes) loại bỏ được $0,15 \mathrm{mg} / \mathrm{L}$ TN, 62,4 $\mathrm{mg} / \mathrm{LTP}, 23,6 \mathrm{mg} / \mathrm{L} \mathrm{NO}_{3}{ }^{-}$. Nghiên cứu của Lê Diễm Kiều và ctv. (2015) cho thấy cỏ mồm mỡ có khả

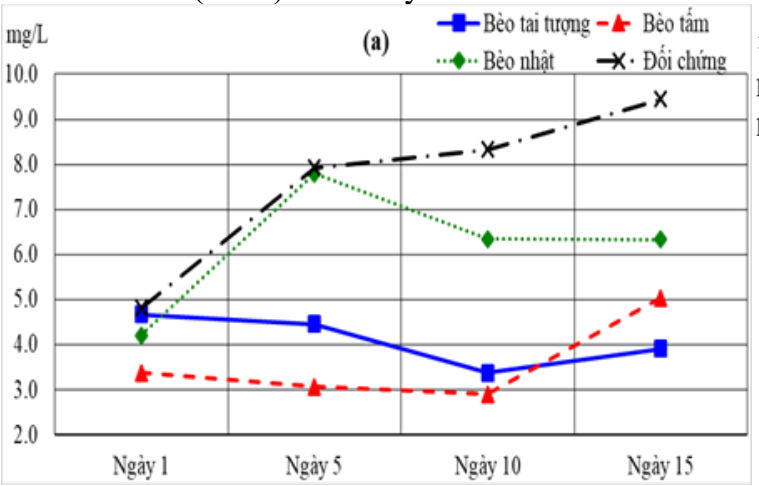

Hình 7. Biến độn

\section{KẾT LUÂN VÀ ĐỀ XUẤT}

Nghiệm thức bổ sung bèo tai tượng ( $P$. tratiotes) cho hiệu quả xử lý tốt nhất trong thời gian 10 ngày đầu của thí nghiệm. Bèo tai tượng có hiệu suất xử lý các chất ô nhiễm tốt, đặc biệt là $\mathrm{NO}_{3}{ }^{-}$và $\mathrm{PO}_{4}{ }^{3-}$ (lần lượt là $46,70 \%$ và $24,56 \%$ so với nồng độ ban đầu). Bèo tai tượng có khả năng làm tăng đến $37,68 \% \mathrm{DO}$, làm giảm $65,83 \% \mathrm{CO}_{2}, 34,28 \% \mathrm{COD}, 40,70 \%$ TAN, và $9,16 \%$ TP ở ngày thứ 10 của thí nghiệm.

Thí nghiệm xác định diện tích bèo tai tượng để xử lý chất thải theo tiêu chuẩn nước thải của bộ tài nguyên và môi trường được đề xuất.

\section{LỜI CẢM ƠN}

Nghiên cứu này được tài trợ bởi Dự án Nâng cấp Trường Đại học Cần Thơ VN14-P6 bằng nguồn vốn vay $\mathrm{ODA}$ từ Chính phủ Nhật Bản.

\section{TÀI LIẸU THAM KHẢO}

Alabaster, J. \& Lloyd R. (1980). Water Quality Criteria for Freshwater Fish. FAO, United Nations, Butterworth, London. năng giúp giảm 69,7-96,9\% $\mathrm{N}-\mathrm{NH}_{4}{ }^{+}, 99,3-99,9 \%$ $\mathrm{N}-\mathrm{NO}_{3}{ }^{-}$và $48,5-73,5 \% \mathrm{TKN}$.

\subsection{Biến động $\mathrm{P}_{-} \mathrm{PO}_{4}{ }^{3-}$ và $\mathrm{TP}$}

Nồng độ $\mathrm{P}_{-} \mathrm{PO}_{4}{ }^{3-}$ và TP ở các NT bèo tai tượng, bèo tấm và bèo nhật giảm thấp vào ngày thứ 10 của thí nghiệm. Ngược lại, $\mathrm{P}_{-} \mathrm{PO}_{4}{ }^{3-}$ và $\mathrm{TP}$ ở $\mathrm{NT}$ đối chứng lại tăng theo thời gian thí nghiệm (Hình 7). Kết quả thí nghiệm cũng cho thấy sau 10 ngày thí nghiệm, NT bèo tai tượng có khả năng hấp thu $24,56 \% \mathrm{P}^{-} \mathrm{PO}_{4}{ }^{3-}$ và $9,16 \% \mathrm{TP}$; NT bèo tấm hấp thu $13,80 \% \mathrm{P}^{-} \mathrm{PO}_{4}{ }^{3-}$ và $15,08 \%$ TP trong khi NT bèo nhật hấp thu $\mathrm{PO}_{4}{ }^{3-}$ rất thấp. Nguyên nhân là vì phospho trong hệ thống xử lý nước bằng thực vật thủy sinh giảm do được thực vật hấp thụ hoặc kết tủa và hấp phụ vào bùn đáy thủy vực (Hastie, 1992).

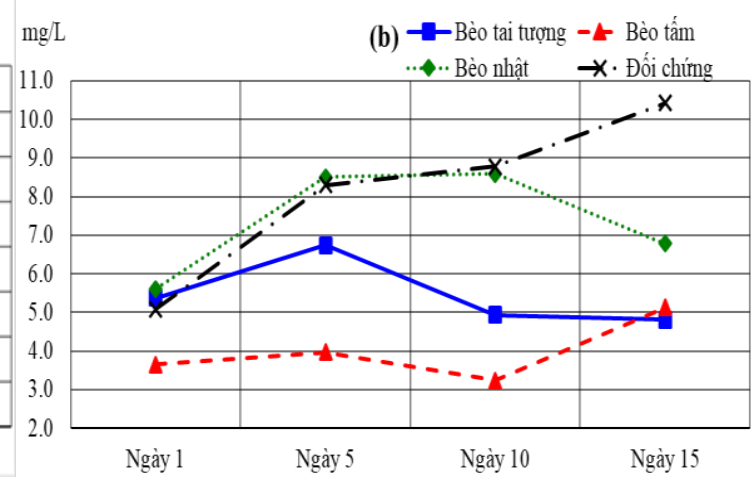

P (b) trong hệ thống thí nghiệm

American Public Health Association, Amarican Water Works Association \& Water Environment Federation (1995). Standard method for the examination of water and wastewater (19th ed). Washington DC.

Boyd, C. E. (1990). Water Quality in Ponds for Aquaculture. Agriculture Experiment Station. Auburn University, Alabama.

Cao, T., Ni, L. \& Ping, X. (2004). Acute Biochemical Responses of a Submersed Macrophyte, Potamogeton crispus L., to High Ammonium in an Aquarium Experiment. Journal of Freshwater Ecology, 19(2), 279-284.

Cao Văn Thích, Phạm Thanh Liêm \& Trương Quốc Phú. (2014). Ảnh hưởng mật độ nuôi đến chất lượng nước, sinh trưởng, tỷ lệ sống của cá lóc (Channa striata) nuôi trong hệ thống tuần hoàn. Tap chi Khoa học Truờng Đại hoc Cần Tho, Số chuyên đề Thủy sản (2), 79-85.

Dinges, R. (1982). Natural systems for water pollution control (Van Nostrand Reinhold environmental engineering series). Van Nostrand Reinhold. 
Roque d'orbcastel, E., Blancheton, J. P., Belaud, A. (2009). Water quality and rainbow trout performance in a Danish Model Farm recirculating system: Comparison with a flow through system. Aquacultural Engineering, 40(3), 135-143. https://doi.org/10.1016/j.aquaeng.2009.02.002

Ferdoushi, Z., Haque, F., Khan, S. \& Haque, M. (2008). The Effects of two Aquatic Floating Macrophytes (Lemna and Azolla) as Biofilters of Nitrogen and Phosphate in Fish Ponds. Turkish Journal of Fisheries and Aquatic Sciences, 8 , 253-258.

EIFAC (European Inland Fisheries Advisory Commission) (1980). Symposium on new developments in the utilization of heated effluent and recirculation systems for intensive aquaculture. Food and Agriculture Organization of the United Nations.

Hastie, B. A. (1992). The use of aquatic plants in wastewater treatment: A literature review (Master thesis of science in engineering). The university of Texas at Austin.

Henry - Silva, G.G. \& Camargo, A. F.M., 2006. Efficiency of aquatic macrophytes to treat Nile tilapia pond effluents. Sci. Agic. (Piacicaba, Braz.), 63(5), 433 - 438. https://doi.org/10.1590/S010390162006000500003

Lai W. L., Wang S. Q., Peng C. L. \& Chen Z. H. (2011). Root features related to plant growth and nutrient removal of 35 wetland plants. Water Research, 45(3), 3941-3950. https://doi.org/10.1016/j.watres.2011.05.002

Lê Diễm Kiều, Phạm Quốc Nguyên, Trần Thị Huỳnh Như \& Ngô Thụy Diễm Trang. (2015). Diễn biến thành phần đạm của nước thải ao nuôi cá tra (Pangasianodon hypophthalmus) thâm canh trong điều kiện thủy canh cỏ mồm mỡ (Hymenachne acutigluma). Tap chi khoa hoc trường Đại hoc Cần Tho, số chuyên đề Môi trương và biến đổi khi hậu, $80-87$.

Lê Hoàng Việt \& Nguyễn Võ Châu Ngân. (2014). Giáo trình kỹ thuật xủ lý nuoóc thải (tập 1, 2). Nhà xuất bản Đại học Cần Thơ.

Li J., Yang X., Wang Z., Shan Y. \& Zheng Z. (2015). Comparison of four aquatic plant treatment systems for nutrient removal from eutrophied water. Bioresource Technology, 179, 1-7. https://doi.org/10.1016/j.biortech.2014.11.053

Martins, C. I. M., Eding, E. H., Verdegema, M. C. J., Heinsbroeka, L. T. N., Schneiderc, O., Blanchetond, J. P., Roque d'Orbcasteld, E., \& Verretha, J. A. J. (2010). New developments in recirculating aquaculture systems in Europe: A perspective on environmental sustainability.
Aquacultural Engineering, 43(3), 83-93. https://doi.org/10.1016/j.aquaeng.2010.09.002

Masser, M. P., Rakocy, J. \& Losordo, T. M. (1999). Recirculating aquaculture tank production systems: management of recirculating systems. SRAC Publication 452.

Metcalf, L. \& Eddy, Inc., (1991). Wastewater Engineering: Treatment, Disposal, and Reuse ( $3^{\text {rd }}$ ed). In Tchobanoglous, G. \& Burton, F. L. (Eds.), New York: McGraw-Hill.

Muir, J. F. (1982). Recirculation systems in aquaculture. In: Muir, J.F and Robers, R. J (editors) Recent Advances in Aquaculture. Croom Helm and Westview Press, London.

Nimptsch, J. \& Pflugmacher, S. (2007). Ammonia triggers the promotion of oxidative stress in the aquatic macrophyte Myriophyllum mattogrossense. Chemosphere, 66(4), 708-714. https://doi.org/10.1016/j.chemosphere.2006.07.064

Nguyễn Thanh Phương, Trần Ngọc Hải, Trần Thị Thanh Hiền \& Marcy N. Wilder. (2003). Nguyên lý và kỹ thuật sản xuất giống tôm càng xanh (Macrobrachium rosenbergii). Nhà xuất bản Nông nghiệp.

Nguyễn Thị Hồng Nho (2013). Cân bằng vật chất dinh duõng trong hệ thống tuần hoàn voong cá tra (Pangasianodon hypophthalmus) (luận văn tốt nghiệp thạc sĩ chuyên ngành Nuôi trồng thủy sản). Trường Đại học Cần Thơ.

Nguyễn Thị Hồng Nho, Huỳnh Thị Kim Hồng \& Phạm Thanh Liêm. (2018). Ảnh hưởng của mật độ nuôi lên chất lượng nước, tăng trưởng và tỉ lệ sống của cá trê vàng (Clarias macrocephalus) trong hệ thống tuần hoàn. Tạp chí Khoa hoc Truờng Đại học Cần Tho, 54(Số chuyên đề thủy sản), 108-114. DOI: 10.22144/ctu.jsi.2018.016

Nguyễn Thị Hồng Nho, Trương Quốc Phú \& Phạm Thanh Liêm. (2019). Ảnh hưởng của phương thức cho ăn lên chất lượng nước, sinh trưởng và tỉ lệ sống của cá trê vàng (Clarias macrocephalus) nuôi trong hệ thống tuần hoàn. Tap chi Khoa học - công nghệ Thủy sản, truờng Đại học Nha Trang, 4, 88-96.

Nho, N.T.H., Liem, P.T. \& Phu, T.Q. (2012). Nutrients mass balance in recirculation system for nursing striped catfish (Pangasianodon hypophthalmus). In: Sharing knowledge for sustainable aquaculture and fisheries in the South-East Asia. Proceedings of the International Fisheries Symposium-IFS 2012, Agriculture Publishing House, 212-216.

Reddy, K.R., D'Angelo, E. M., \& DeBusk, T. A. (1989). Oxygen Transport Through Aquatic Macrophytes: The Role in Wastewater Treatment. Journal of Environmental Quality. 19(2), 261-267. 
https://doi.org/10.2134/jeq1990.0047242500190 0020011x

Tal, Y., Schreier, H. J., Sowers, K. R., Stubblefield, J. D., Place, A. R. and Zohar, Y. (2009).

Environmentally sustainable land-based marine aquaculture. Aquaculture, 286(1-2), 28-35. https://doi.org/10.1016/j.aquaculture.2008.08.043

Tanner C. C., Kadlec, R. H., Gibbs, M. M., Sukias, J. P. S., \& Nguyen, M. L. (2002). Nitrogen processing gradients in subsurface-flow treatment wetlands - influence of wastewater characteristics. Ecological Engineering, 18(4), 499-520. https://doi.org/10.1016/S09258574(02)00011-3

The Interstate Technology and Regulatory Council. (2009). Evaluating Natural Source Zone at Sites with LNAPL. The Interstate Technology \& Regulatoty Council LNAPLs Team, Technology Overview.

Timmons, M.B. \& Ebeling, J. M. (2010). Recirculating Aquaculture (2nd Edition). NRAC Publication No. 401- 2010.
Trịnh Xuân Ngọ \& Đinh Thế Lộc (2011). Giáo trình nông hoc đại cuơng. Trường Đại học Công nghiệp thành phố Hồ Chí Minh.

Trương Thị Nga, Lương Nhã Ca, Trương Hoàng Đan, Nguyễn Xuân Lộc \& Nguyễn Công Thuận. (2007). Xử lý nước thải chăn nuôi bằng bèo tai tượng (pistia stratiotes) và bèo tai chuột (salvinia cucullata). Khoa Hoc Đất, 28, 80-83.

Wafaa A.E., Gahiza I., Farid, A.E., Tarek, T. \& Doaa, H. (2007). Assessment of the efficiency of duckweed (lemna gibba) in wastewater treatment. International journal of Agriculture and Biology, 9(5), 681-687.

Zohar, Y., Tal, Y., Schreier, H.J., Steven, C.R., Stubblefield, J.D. \& Place, A.R. (2005).

Commercially feasible urban recirculating aquaculture: addressing the marine sector. In: Desbonnet, A., Edwards, P. and Baker, D., Costa-Pierce, B. (Ed.), Urban Aquaculture (pp 159 - 171). CABI Publishing. DOI:10.1079/9780851998299.0159 